JKTP Vol 3 No (2) Bulan (Tahun): 187-198

DOI: $10.17977 /$ um038v3i22020p187

JKTP Jurnal Kajian Teknologi Pendidikan

http://journal2.um.ac.id/index.php/jktp/index

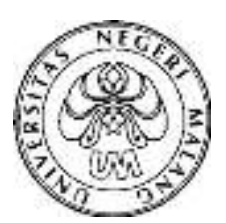

\title{
PENGEMBANGAN MULTIMEDIA DRILL AND PRACTICE MENINGKATKAN KECAKAPAN BAHASA JEPANG UNGKAPAN SEHARI-HARI
}

\author{
Fara Nabila Gunawan, Yerry Soepriyanto, Agus Wedi \\ Jurusan Teknologi Pendidikan, Fakultas Ilmu Pendidikan, Universitas Negeri Malang \\ Jalan Semarang 5 Malang 65145 0341-574700 \\ Email: yerry.soepriyanto.fip@um.ac.id
}

\section{Article History}

Received: 25-04-2020

Accepted: $30-04-2020$

Published: 20-05-2020

\section{Keywords}

Multimedia; Drill and

Practice; Bahasa Jepang

Ungkapan Sehari-Hari

\section{Abstrak}

Drill and practice merupakan metode pembelajaran yang diterapkan dalam multimedia pembelajaran dimana siswa melaksanakan kegiatan latihan yang nantinya keterampilan tersebut menjadi kebiasaan. Hal ini dapat diterapkan saat belajar Bahasa Jepang, mengingat banyak siswa yang kurang tertarik dikarenakan metode pembelajaran yang masih konvensional. Penelitian dan pengembangan bertujuan untuk menghasilkan produk program aplikasi multimedia drill and practice ungkapan sehari-hari yang diaplikasikan pada media pembelajaran Bahasa Jepang di SMAN 9 Malang. Produk yang dikembangkan memiliki rincian yaitu konten materi serta bentuk konten dan pengemasan. Pada penelitian ini menerapkan metode pengembangan Lee \& Owens. Validasi ahli media dengan data kuantitatif menghasilkan persentase $93 \%$ dan termasuk dalam kriteria (76\%-100\%) dan dikategorikan valid. Validasi ahli materi dengan data kuantitatif menghasilkan persentase $92 \%$. Sehingga dapat disimpulkan bahwa produk multimedia drill and practice Bahasa Jepang tersebut termasuk dalam kriteria valid atau dapat diaplikasikan untuk pembelajaran.

\footnotetext{
Abstract

Drill and practice is a learning method that is applied in multimedia learning where students carry out training activities which later these skills become habits. This can be applied when learning Japanese, considering that many students are less interested due to conventional learning methods. Research and development aims to produce a multimedia application program drill and practice everyday expressions that are applied to Japanese language learning media at SMAN 9 Malang. The product developed has details namely material content as well as content and packaging forms. In this study applying the Lee $\&$ Owens development method. Validation of media experts with quantitative data yields a percentage of $93 \%$ and is included in the criteria $(76 \%-100 \%)$ and is categorized valid. Material expert validation with quantitative data yields a percentage of $92 \%$. So it can be concluded that the Japanese multimedia drill and practice product is included in the valid criteria or can be applied for learning.
} 


\section{PENDAHULUAN}

Saat ini, perkembangan teknologi dapat memudahkan proses pembelajaran dengan memperoleh informasi dimana pun dan kapan pun. Pembelajaran merupakan proses hubungan guru dengan siswa menggunakan sumber belajar yang terjadi dalam lingkup pendidikan dengan saling bertukar informasi. Menurut Instructional Technologies The Definition and Domains of The Field (1994), AECT (Association for Educational Communication and Technology) ragam sumber belajar yang diterapkan pada pembelajaran, adalah pesan, orang, bahan, alat, teknik, dan latar. Namun, saat ini telah banyak digunakan guru sumber belajar yang berupa multimedia pembelajaran yang mampu menarik minat siswa saat ini untuk lebih mengedepankan teknologi.

Media dapat disebut sebagai alat ataupun sarana yang diterapkan untuk perantara pada kegiatan komunikasi antara pemberi pesan dan penerima pesan, Sihkabuden (2011:3). Berdasarkan pengertian tersebut maka media pembelajaran mampu mengubah metode pembelajaran dari teacher center menuju student center. Pembelajaran student center tidak dapat dipisahkan dari media pembelajaran. Media pembelajaran sebagai jembatan informasi yang tepat untuk menciptakan pembelajaran yang berpusat pada siswa. (Antika, 2014) menjelaskan bahwa keberhasilan pembelajaran berbasis Student Centered Learning didukung penuh dengan media serta sumber belajar yang cukup memadai. Tidak hanya itu Mediawati (2011:68) berpendapat bahwa "media pembelajaran mampu membangkitkan motivasi dan minat peserta didik, media juga dapat membantu peserta didik meningkatkan pemahaman, menyajikan data yang menarik dan terpercaya, memudahkan penafsiran data, dan memadatkan informasi".

Pada lingkup pendidikan, media sebagai alat ataupun sarana pembelajaran yang disiapkan oleh pendidik di kelas dan digunakan oleh siswa secara mandiri. Media pembelajaran jika disajikan dengan baik dan benar mampu mengubah cara peserta didik dalam memperoleh informasi serta mengubah cara belajar peserta didik. Media pembelajaran dalam dunia pendidikan bermacammacam seperti multimedia interaktif, presentasi, hypermedia, tutorial dan drill and practice. Drill and practice bisa disebut metode mengajar yang dilaksanakan oleh siswa dalam bentuk kegiatan latihan yang nantinya keterampilan tersebut menjadi sebuah kebiasaan dan peserta didik nyaman mempelajari materi tersebut dengan diasah terus menerus. Drill and practice membuat peserta didik memperoleh kecakapan motorik, biasanya pembelajaran bahasa dan matematika dasar sering menggunakan drill and practice.

Penelitian yang berjudul "Pengaruh Penggunaan Media Pembelajaran E-Learning Quipper School Terhadap Hasil Belajar Lintas Minat Biologi pada Siswa Kelas X Bahasa Semester Genap di SMA Negeri 1 Sawan" membuktikan bahwa siswa yang mengaplikasikan media pembelajaran mendapatkan hasil belajar yang meningkat, Saraswati, dkk. (2018). Pada penelitian lain dengan judul "Pengaruh media Augmented Reality tata cara penulisan huruf Jepang (Hiragana dan Katakana) Pada Mata Pelajaran Bahasa Jepang Terhadap Hasil Belajar Siswa" menyatakan bahwa memperoleh hasil belajar yang meningkat pada siswa yang mengaplikasikam media pembelajaran augmented reality (Julianti \& Putrama, 2018).

Berdasarkan observasi yang telah dilakukan di SMAN 9 Malang, diketahui bahwa sekolah telah menyediakan beberapa media pembelajaran, diantaranya LCD proyektor, komputer. Selain itu untuk menunjang proses pembelajaran sekolah juga memiliki laboratorium bahasa dan laboratorium komputer di setiap program keahlian. Fasilitas-fasilitas tersebut sudah disediakan sekolah namun, ternyata dalam pelaksanaan pembelajaran media tersebut belum mampu dimanfaatkan secara optimal. Komputer merupakan media yang memiliki kemampuan interaksi paling baik. Namun, pemanfaatan komputer sebagai media pembelajaran masih kurang karena tidak ada media pembelajaran berbasis komputer yang dimanfaatkan di sekolah.

Setelah melakukan wawancara kepada guru Bahasa Jepang, dapat diketahui bahwa dalam proses pembelajaran teori memang cenderung monoton, selama ini siswa hanya diberi ceramah oleh guru, materi pelajaran banyak namun, guru merasa jam pelajaran masih kurang. Belum ada media pembelajaran apapun yang bisa diaplikasikan siswa secara mandiri, namun beliau merasa bila ada media pembelajaran sangat membantu guru dan siswa. Guru menambahkan bahwa hal ini memang 
belum sesuai dengan kurikulum 2013, sebenarnya guru mengetahui bahwa kurikulum 2013 mengharuskan pembelajaran berpusat pada siswa. Pembelajaran interaktif salah satunya menggunakan media, dan pembelajaran yang mampu menyesuaikan dengan kebutuhan setiap peserta didik.

Dalam pembelajaran Bahasa Jepang guru mengungkapkan beberapa pokok bahasan yang dirasa cukup sulit oleh siswa, salah satunya materi ungkapan sehari-hari Bahasa Jepang. Materi pelajaran ungkapan sehari-hari merupakan dasar yang cukup penting. Namun saat pembelajaran guru mengungkapkan banyak siswa yang kurang mampu menguasai dasar ini. Guru menjelaskan bahwa saat pembelajaran beberapa siswa meminta untuk mengulang kembali penjelasan guru. Beliau juga mengungkapkan bahwa belajar disekolah saja memang terkadang tidak cukup untuk menguasai materi yang cukup sulit. Selain itu pembelajaran yang sebagian besar teacher center juga menyebabkan siswa tidak memperhatikan saat pembelajaran.

Berdasarkan pemaparan diatas tentang hasil observasi dan wawancara di SMAN 9 Malang di atas, menunjukkan bahwa pembelajaran konvensional yang dilaksanakan guru masih memiliki beberapa kekurangan. Beberapa siswa merasa kurang memahami materi ungkapan sehari-hari dalam Bahasa Jepang, pembelajaran cenderung monoton dan kurang sesuai dengan kurikulum 2013, serta belum ada media pembelajaran berbasis komputer yang dimanfaatkan. Mengingat beberapa kekurangan dari pembelajaran konvensional, pembelajaran bisa dikombinasikan dengan media pembelajaran yang lebih inovatif dan interaktif.

Media pembelajaran memang begitu penting namun pemilihan media pembelajaran juga tidak bisa begitu saja. Agar media menjadi alat penyalur informasi yang baik untuk pembelajaran pemilihan media hendaknya mempermudah siswa menyerap materi. Selain itu, media pembelajaran harus sesuai dengan keadaan siswa. Menurut Paivio (2006) dalam teorinya Dual-Coding Theory manusia akan lebih mudah belajar ketika media belajar yang digunakan menggunakan dua gaya belajar yaitu verbal dan visual. Hal itu berdampak pada kemudahan penyerapan informasi yang disampaikan. Begitu juga, memori informasi visual sering dapat ditingkatkan ketika dipasangkan dengan informasi verbal yang relevan, baik di dunia nyata atau yang dibayangkan (Anderson \& Bower, 1973).

Salah satu alternatif yaitu mengembangkan media pembelajaran berbasis komputer. Pembelajaran Bahasa Jepang pada materi ungkapan sehari-hari menggunakan media pembelajaran berbasis komputer dapat disampaikan dengan berbagai bentuk penyajian sehingga menjadi lebih jelas. Siswa memahami dasar Bahasa Jepang berupa ungkapan sehari-hari melalui kegiatan interaktif, bukan hanya menghafal.

Hasil penelitian sebelumnya yang berjudul "The Use of Drill, Vocabulous (Vocabulary Various) and Computer Assisted Language Learning (Call) in Learning Vocabular" (Fauzia, 2018) membuktikan bahwa pembelajaran multimedia drill and practice memiliki efek positif dan linear kemampuan visual pada hasil belajar siswa. Dalam penelitian lain yang berjudul "Penerapan Model Pembelajaran Drill and Practice terhadap Hasil Belajar Chest Pass pada Permainan Bola Basket (Studi Pada Siswa Kelas X SMA Negeri 1 Kota Mojokerto)" (Candra \& Sudarso, 2014) membuktikan mampu meningkatkan motivasi dan hasil belajar siswa.

\section{Multimedia}

Media dapat disebut sebagai alat atau sarana yang digunakan untuk perantara pada kegiatan komunikasi antara pemberi pesan dan penerima pesan, Sihkabuden (2011:3). Terdapat tujuh elemen dalam multimedia menurut Munir (2015), yaitu teks, grafik, gambar, video, animasi, audio, dan interaktivitas. Menurut Ricardh Mayer (2010) terdapat sepuluh prinsip yang harus ada di dalam desain pengembangan multimedia yaitu prinsip multimedia, kesinambungan spasial, kesinambungnan waktu, koherensi, modalitas belajar, redudansi, personalisasi, interaktivitas, sinyal (cue, highlight) dan perbedaan individu. 
Daryanto (2013: 52) berpendapat bahwa "multimedia pembelajaran adalah aplikasi multimedia yang digunakan dalam proses pembelajaran, dengan kata lain untuk menyalurkan pesan (pengetahuan, keterampilan dan sikap) serta dapat merangsang pikiran, perasaan, perhatian dan kemauan siswa sehingga secara sengaja proses belajar terjadi, bertujuan dan terkendali”. Multimedia pembelajaran adalah penggunaan komputer untuk menciptakan, menggabungkan, serta menyampaikan konten pembelajaran yang dimuat dalam bentuk grafik, teks, audio, gambar bergerak dengan menyatukan alat yang dapat digunakan pengguna untuk berkreasi, berinteraksi, berkomunikasi dan melakukan navigasi.

\section{Drill and Practice}

Pendapat Roestiyah (2010:125), drill and practice adalah metode membimbing siswa dengan menerapkan kegiatan latihan supaya siswa mempunyai kemampuan yang baik dari yang ditekuni. Sedangkan menurut Shalahuddin (1987:100), drill and practice merupakan melakukan kegiatan berulang-ulang untuk meningkatkan keterampilan agar terbiasa. Metode ini memiliki ciri yang khas yaitu tindakan berulang dari hal yang sama.

Metode pembelajaran drill and practice memiliki tujuan supaya peserta didik menguasai keterampilan motorik diantaranya menulis, mengingat kata, menggunakan alat untuk menghasilkan kreasi, dan melakukan gerakan olah raga. Tidak hanya keterampilan motorik namun, siswa juga dapat mengembangkan kemampuan berpikir, seperti pada pelajaran matematika, kimia, dan bahasa.

Drill and practice juga memiliki fungsi yang mampu memberikan motivasi lebih kepada siswa dengan adanya komponen multimedia yang membuat siswa tertarik sehingga memotivasi untuk belajar. Metode drill and practice juga dapat menambah atau memperkaya sistem pembelajaran tradisional yang sebagian besar berfokus pada guru dalam menyampaikan pendapat dengan metode ceramah atau yang lainnya dengan adanya metode drill and practice siswa lebih dominan meskipun peran guru juga masih dibutuhkan untuk mengawasi setiap kemajuan siswa.

Menurut Sumiati dan Asra (2011:105), keberhasilan metode drill and practice, guru berkewajiban untuk memperhatikan proses yang dibuat seperti menggunakan kegiatan latihan untuk pelajaran atau tindakan lainnya, memilih latihan yang mampu menumbuhkan makna, pengertian, dan, tujuan dari latihan sebelum peserta didik melakukan kegiatan, mengutamakan ketepatan, memperhatikan reaksi peserta didik yang dilaksanakan dengan benar dan efektif, mempertimbangkan waktu latihan yang efektif supaya siswa tidak lelah dan bosan serta memperhatikan perbedaan setiap siswa.

\section{Pembelajaran Bahasa Jepang}

Pembelajaran Bahasa Jepang merupakan pembelajaran yang membahas tentang bahasa dan budaya Jepang secara rinci dan mudah dipahami oleh siswa. Pembelajaran Bahasa Jepang dapat ditemukan di SMA seluruh Indonesia. Namun, tidak semua SMA memberikan pembelajaran Bahasa Jepang hanya SMA tertentu saja. Salah satu bahasa asing yang diajarkan di jurusan bahasa yang ada di SMA adalah Bahasa Jepang. Pembelajarannya berisi tentang bagaimana kehidupan masyarakat Jepang serta bahasa yang digunakan dalam sehari-hari. Salam sapaan dan ungkapan, lingkungan sekolah, anggota keluarga, lingkungan rumah, pekerjaan, huruf jepang, budaya jepang, benda-benda di lingkungan sekitar, dan lain-lain. Pokok bahasan di atas merupakan materi yang diberikan guru dalam pembelajaran Bahasa Jepang agar siswa paham budaya dan Bahasa Jepang.

\section{Multimedia Drill and Practice Bahasa Jepang Pokok Bahasan Ungkapan Sehari-hari}

Multimedia ini diciptakan untuk melatih siswa dalam menambah kosa kata atau dapat dikatakan menghafalkan kosa kata dalam Bahasa Jepang khususnya dalam pokok bahasan ungkapan sehari-hari. Dengan melatih siswa secara terus menerus membuat siswa hafal dan terbiasa dengan kosa kata baru sehingga mereka terbiasa dan nyaman menggunakan kosa kata baru tersebut dalam proses pembelajaran. 
Di dalam media pembelajaran diberikan beberapa macam soal yang mampu melatih siswa agar terbiasa dan hafal dengan kosa kata baru. Pada setiap soal terdapat komponen multimedia seperti audio, gambar, teks, animasi yang mampu membuat siswa tertarik dengan media pembelajaran tersebut.

Komponen teks berupa soal-soal ungkapan sehari-hari yang disuguhkan dengan berbagai macam variasi seperti Bahasa Jepang huruf hiragana, bacaan Jepang latin, dan artinya. Gambar diikut sertakan agar siswa mempunyai ilustrasi untuk menjawab soal yang diberikan atau bisa disebut pelengkap komponen teks. Soal tidak hanya menggunakan teks namun, juga menyajikan soal berupa audio yang bisa menarik siswa dengan gaya belajar auditory, tentunya dengan menggunakan komponen teks juga. Namun, tidak memerlukan gambar lagi karena akan terjadi tumpang tindih fokus siswa dalam menjawab soal tentang ungkapan sehari-hari

Ungkapan sehari-sehari dalam materi Bahasa Jepang merupakan pembelajaran dasar yang mempelajari apa saja ungkapan yang digunakan masyarakat Jepang dalam keseharian mereka beraktivitas. Dalam media pembelajaran ini terdapat sepuluh ungkapan sehari-hari masyarakat Jepang yang sering digunakan dan harus dipahami oleh siswa. Ungkapan tersebut seperti ungkapan terima kasih, sama-sama, meminta maaf, memperkenalkan diri, selamat datang, selamat makan, selamat, semangat, iya, dan tidak. Setiap ungkapan menggunakan variasi soal yang berbeda-beda, untuk 9 soal ungkapan menggunakan teks dan gambar dan 1 soal menggunakan audio dan teks.

Media pembelajaran ini dibuat juga sebagai bentuk menunjang guru saat menyajikan materi dengan cara yang berbeda memanfaatkan media pembelajaran yang sebelumnya guru menggunakan metode ceramah dan power point sehingga menyebabkan siswa jenuh dan susah mencerna materi. Mata pelajaran yang bukan bahasa asing saja siswa terkadang malas dan bosan saat guru menjelaskan hanya menggunakan power point, bagaimana jika materi bahasa asing yang tidak pernah siswa pelajari sebelumnya, jadi harus menggunakan media yang inovatif dan kreatif untuk siswa.

\section{METODE}

Rancangan penelitian ini mencakup seluruh proses pengembangan yang sistematis sesuai dengan metode pengembangan yang digunakan. Produk yang dikembangkan adalah aplikasi multimedia drill and practice dengan materi ungkapan sehari-hari Bahasa Jepang untuk kelas $\mathrm{X}$ bahasa di SMAN 9 Malang. Pembuatan aplikasi ini menggunakan aplikasi Lectora Inspire 18.

Metode pengembangan yang digunakan adalah Lee \& Owens (2004). Alasan peneliti menggunakan metode pengembangan Lee \& Owens (2004) karena metode pengembangan ini mempunyai tahapan rinci dan lengkap, mulai dari analisis dan penilaian, desain, pengembangan, implementasi, dan evaluasi yang dirasa sangat tepat untuk pengembangan produk multimedia drill and practice. Selain itu metode pengembangan ini ditujukan untuk pengembangan multimedia pembelajaran.

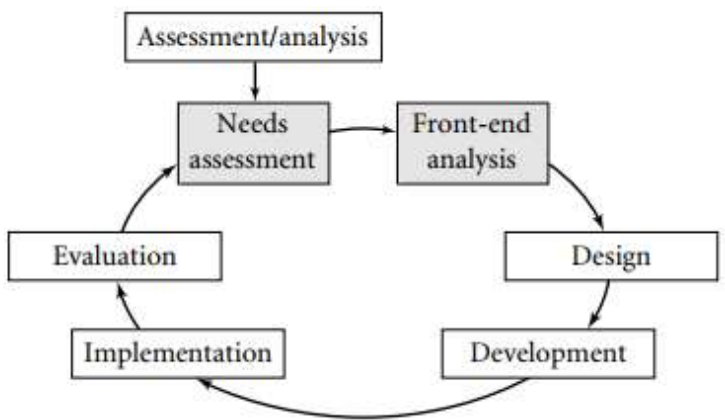

Gambar 1. Model Pengembangan Lee \& Owens Sumber: Lee \& Owens (2004:3) 
Prosedur penelitian dan pengembangan multimedia drill and practice sesuai dengan metode pengembangan Lee \& Owens adalah sebagai berikut: (1) Assessment/analisis yang terdiri dari 2 bagian utama yaitu analisis kebutuhan dan analisis Front-End; (2) Desain; (3) Pengembangan; (4) Implementasi; (5) Evaluasi. Namun pada penelitian ini hanya akan dilaksanakan hingga tahap Development/Pengembangan.

Kegiatan uji validitas dan uji coba produk dalam pengembangan dilaksanakan untuk mendapatkan data yang dimanfaatkan untuk menentukan tingkat kevalidan multimedia drill and practice. Kegiatan tersebut terdiri dari desain validasi (validasi ahli materi dan ahli media), subjek validasi dan uji coba (ahli media dan ahli materi).

Jenis data yang didapat dari pengembangan multimedia drill and practice ungkapan seharihari Bahasa Jepang ini adalah data kuantitatif dan data kualitatif. Data kualitatif berbentuk kritik, saran, dan pendapat tentang multimedia pembelajaran yang dikembangkan oleh peneliti dari ahli media dan ahli materi. Sedangkan data kuantitatif berupa penilaian terhadap multimedia pembelajaran yang dikembangkan oleh peneliti dari angket hasil validasi ahli.

Instrumen yang diterapkan untuk mengetahui validitas produk pengembangan adalah angket. Penilaian angket validasi oleh ahli media dan ahli materi menggunakan jenis pengukuran skala likert dengan empat jawaban yaitu, SS (Sangat Setuju), S (Setuju), TS (Tidak Setuju) dan STS (Sangat Tidak Setuju). Pada angket validasi ahli media aspek yang dinilai seperti fungsi dan manfaat, aspek visual media, aspek audio media, aspek tipografi, aspek bahasa, dan aspek pemrograman. Aspek fungsi dan manfaat berupa memperjelas dan mempermudah penyampaian pesan, membangkitkan minat dan motivasi siswa, dan membangkitkan kreativitas siswa. Aspek visual media berisi kemenarikan warna, background, gambar, dan audio, kesesuaian ukuran gambar, serta kejelasan gambar. Aspek audio seperti ritme suara, kejelasan suara, dan kesesuaian suara dengan materi. Aspek berikutnya merupakan tipografi yang berisi tentang pemilihan jenis teks dan ketepatan ukuran teks. Aspek yang paling penting yaitu aspek bahasa yang berisi tentang ketepatan bahasa, efektivitas kata, istilah, dan kalimat, serta kemudahan memahami alur materi melalui penggunaan bahasa. Aspek yang terakhir yaitu aspek pemrograman media yang berisi tentang kemutakhiran media pembelajaran.

Angket validasi ahli materi juga memiliki berbagai aspek yang dinilai seperti keakuratan materi, koherensi dan keruntutan materi, serta kemutakhiran materi. Aspek keakuratan materi indikator yang dinilai seperti keakuratan konsep dan definisi, keakuratan data dan fakta, keakuratan contoh dan kasus, keakuratan ilustrasi, keakuratan istilah-istilah, keakuratan gambar, dan keakuratan petunjuk penggunaan. Aspek koherensi dan keruntutan materi berisi ketertautan antar kegiatan belajar/sub kegiatan belajar/alinea, keutuhan makna dalam kegiatan belajar/sub kegiatan belajar/alinea, keruntutan materi, dan kesesuaian penggunaan waktu mengerjakan soal. Aspek yang terakhir untuk validasi ahli materi adalah aspek kemuktahiran materi yang berisi kesesuaian materi dengan perkembangan ilmu pengetahuan, ilustrasi dalam kehidupan sehari -hari, menggunakan contoh kasus yang terdapat dalam kehidupan sehari-hari, dan kesesuaian hasil atau penilaian.

Berdasarkan penilaian oleh ahli media dan ahli materi dianalisis dengan teknik analisis kualitatif dan kuantitatif. Data kualitatif dianalisis menggunakan analisis isi, saran, tanggapan, dan kritik dari validator. Sedangkan data kuantitatif dianalisis menggunakan teknik analisis persentase. Teknik analisis persentase adalah cara untuk mengubah data kuantitatif menjadi bentuk persentase setelah itu dijelaskan menggunakan kalimat yang bersifat kualitatif. Teknik analisis ini digunakan untuk menjelaskan hasil pengembangan produk berupa multimedia drill and practice serta menguji tingkat kelayakan produk yang dikembangkan.

\section{HASIL}

Data hasil validasi produk pengembangan media pembelajaran dilaksanakan dalam dua tahap. Tahap pertama didapat dari penilaian validasi ahli media oleh salah satu dosen Teknologi Pendidikan UM, tahap kedua dari guru mata pelajaran Bahasa Jepang di SMAN 9 Malang. Data 
hasil validasi produk pengembangan media pembelajaran yang diperoleh pada penelitian ada dua, yaitu data kuantitatif dan data kualitatif, data tersebut didapat melewati tahap validasi. Data kuantitatif berupa angka sedangkan data kualitatif berupa saran-saran yang diberikan oleh ahli media dan ahli materi.

Tabel 1. Penyajian Data Hasil Validasi Ahli Media

\begin{tabular}{|c|c|c|c|c|c|}
\hline No. & Indikator & Sub Indikator & $\mathbf{X}$ & $\mathbf{X 1}$ & Presentase \\
\hline \multirow[t]{3}{*}{1.} & Fungsi dan Manfaat & $\begin{array}{l}\text { Memperjelas dan mempermudah } \\
\text { penyampaian pesan. }\end{array}$ & 4 & \multirow{3}{*}{12} & $100 \%$ \\
\hline & & $\begin{array}{l}\text { Membangkitkan minat dan motivasi } \\
\text { siswa }\end{array}$ & 3 & & $75 \%$ \\
\hline & & Membangkitkan kreativitas siswa & 3 & & $75 \%$ \\
\hline \multirow[t]{3}{*}{2.} & Aspek visual media & $\begin{array}{l}\text { Kemenarikan warna, background, } \\
\text { gambar, dan audio }\end{array}$ & 4 & \multirow{3}{*}{12} & $100 \%$ \\
\hline & & Kesesuaian ukuran gambar & 4 & & $100 \%$ \\
\hline & & Kejelasan gambar & 4 & & $100 \%$ \\
\hline \multirow[t]{3}{*}{3.} & Aspek audio media & Ritme suara & 3 & \multirow{3}{*}{12} & $75 \%$ \\
\hline & & Kejelasan suara & 4 & & $100 \%$ \\
\hline & & Kesesuaian suara dengan materi & 3 & & $75 \%$ \\
\hline \multirow[t]{2}{*}{4.} & Aspek tipografi & Pemilihan jenis teks & 4 & \multirow{2}{*}{8} & $100 \%$ \\
\hline & & Ketepatan ukuran teks & 4 & & $100 \%$ \\
\hline \multirow[t]{3}{*}{5.} & Aspek bahasa & Ketepatan bahasa & 4 & \multirow{3}{*}{12} & $100 \%$ \\
\hline & & Efektivitas kata, istilah dan kalimat & 4 & & $100 \%$ \\
\hline & & $\begin{array}{l}\text { Kemudahan memahami alur materi } \\
\text { melalui penggunaan bahasa }\end{array}$ & 4 & & $100 \%$ \\
\hline \multirow[t]{2}{*}{6.} & $\begin{array}{l}\text { Aspek pemrograman } \\
\text { media }\end{array}$ & Kemutakhiran media & 3 & 4 & $75 \%$ \\
\hline & & Total & 56 & 60 & $93 \%$ \\
\hline
\end{tabular}

Dari hasil penilaian ahli media untuk data kuantitatif, dapat diperoleh analisis bahwa dari 15 aspek terdapat 11 item yang memiliki persentase sebesar $100 \%$ dan masuk dalam kriteria (76\%$100 \%$ ) dengan kategori valid yakni pada aspek berikut: (1) Memperjelas dan mempermudah penyampaian pesan; (4) Kemenarikan warna, background, gambar, dan audio; (5) Kesesuaian ukuran gambar; (6) Kejelasan gambar; (8) Kejelasan suara; (9) Kesesuaian suara dengan materi; (10) Pemilihan jenis teks; (11) Ketepatan ukuran teks; (12) Ketepatan bahasa; (13) Efektivitas kata, istilah, dan kalimat; (14) Kemudahan memahami alur materi melalui penggunaan bahasa. Sedangkan pada aspek lain yang memiliki persentase sebesar 75\% dan masuk dalam kriteria (51\%75\%) dengan kategori cukup valid yaitu: (2) Membangkitkan minat dan motivasi siswa; (3) Membangkitkan kreativitas siswa; (7) Ritme suara; (15) Kemutakhiran media. Analisis yang telah dilaksanakan terhadap pendapat ahli media diperoleh hasil 93\%. Berdasarkan kriteria yang ditetapkan dapat disimpulkan bahwa Multimedia Drill and Practice Mata Pelajara Bahasa Jepang Materi Ungkapan Sehari-Hari memenuhi kriteria valid dan layak digunakan sebagai media pembelajaran.

Untuk data kualitatif berisi komentar, kritik dan saran yang diberikan oleh ahli media. Multimedia pembelajaran drill and practice sudah cukup menarik untuk digunakan pada pembelajaran. Hanya perlu diperbaiki untuk tombol play diberi keterangan, audio pembuka dan penutup serta penguatan untuk hasil belajar. Komentar, kritik, dan saran yang diberikan oleh ahli media mampu meningkatkan kelayakan multimedia pembelajaran untuk selanjutnya. 
Penyajian data validasi materi berupa hasil jawaban dari ahli materi. Proses pengolahan data tersebut menggunakan rumus yang telah ditentukan serta pedoman interpretasi data disesuaikan berdasarkan kriteria yang sudah ditentukan. Sama halnya dengan ahli media, validasi ahli materi juga menggunakan data kuantitatif dan kualitatif. Data kuantitatif berupa angka sedangkan data kualitatif berupa saran yang diberikan oleh ahli materi.

Tabel 2. Penyajian Data Hasil Validasi Ahli Materi

\begin{tabular}{|c|c|c|c|c|c|}
\hline No. & Indikator & Sub Indikator & $\mathbf{X}$ & $\mathbf{X 1}$ & Presentase \\
\hline \multirow[t]{8}{*}{1.} & Keakuratan Materi & Keakuratan konsep dan definisi. & 4 & \multirow{9}{*}{28} & $100 \%$ \\
\hline & & Keakuratan data dan fakta. & 4 & & $100 \%$ \\
\hline & & Keakuratan contoh dan kasus. & 4 & & $100 \%$ \\
\hline & & Keakuratan ilustrasi. & 4 & & $100 \%$ \\
\hline & & Keakuratan istilah-istilah. & 4 & & $100 \%$ \\
\hline & & Keakuratan gambar & 4 & & $100 \%$ \\
\hline & & Keakuratan petunjuk penggunaan & 3 & & $75 \%$ \\
\hline & & Ketertautan antar kegiatan belajar/sub & 3 & & $75 \%$ \\
\hline \multirow[t]{4}{*}{2.} & Koherensi dan & kegiatan belajar/alinea. & 3 & & \\
\hline & Keruntutan Materi & $\begin{array}{l}\text { Keutuhan makna dalam kegiatan } \\
\text { belajar/sub kegiatan belajar/alinea. }\end{array}$ & 3 & \multirow[t]{3}{*}{16} & $75 \%$ \\
\hline & & Keruntutan materi & 4 & & $100 \%$ \\
\hline & & $\begin{array}{l}\text { Kesesuaian penggunaan waktu } \\
\text { mengerjakan soal }\end{array}$ & 4 & & $100 \%$ \\
\hline \multirow[t]{5}{*}{3.} & Kemutakhiran Materi & $\begin{array}{l}\text { Kesesuaian materi dengan } \\
\text { perkembangan Ilmu Pengetahuan }\end{array}$ & 3 & \multirow{4}{*}{16} & $75 \%$ \\
\hline & & Ilustrasi dalam kehidupan sehari -hari & 4 & & $100 \%$ \\
\hline & & $\begin{array}{l}\text { Menggunakan contoh kasus yang } \\
\text { terdapat dalam kehidupan sehari-hari. }\end{array}$ & 3 & & $75 \%$ \\
\hline & & Kesesuaian hasil atau penilaian & 4 & & $100 \%$ \\
\hline & & Total & 55 & 60 & $92 \%$ \\
\hline
\end{tabular}

Dari hasil penilaian ahli materi untuk data kuantitatif, dapat diperoleh analisis bahwa dari 15 aspek terdapat 10 item yang memiliki persentase sebesar $100 \%$ dan masuk dalam kriteria (76\%100\%) dengan kategori valid yakni pada aspek berikut: (1) Keakuratan konsep dan definisi; (2) Keakuratan data dan fakta; (3) Keakuratan contoh dan kasus; (4) Keakuratan ilustrasi; (5) Keakuratan istilah-istilah; (6) Keakuratan gambar; (10) Keruntutan materi; (11) Kesesuaian penggunaan waktu mengerjakan soal; (13) Ilustrasi dalam kehidupan sehari-hari; (15) Kesesuaian hasil dan penilaian. Sedangkan pada aspek lain yang memiliki persentase sebesar $75 \%$ dan termasuk dalam kriteria (51\%-75\%) dengan kategori cukup valid yaitu: (7) Keakuratan petunjuk penggunaan; (8) Ketertautan antar kegiatan belajar/sub kegiatan belajar/alinea.; (9) Keutuhan makna dalam kegiatan belajar/sub kegiatan belajar/alinea; (12) Kesesuaian materi dengan perkembangan Ilmu Pengetahuan; (14) Menggunakan contoh kasus yang terdapat dalam kehidupan sehari-hari. Analisis yang telah dilaksanakan terhadap pendapat ahli materi diperoleh hasil 92\%. Berdasarkan kriteria yang ditetapkan dapat disimpulkan bahwa Multimedia Drill and Practice Mata Pelajaran Bahasa Jepang Materi Ungkapan Sehari-hari memenuhi kriteria valid dan layak digunakan sebagai media pembelajaran.

Untuk data kualitatif berisi komentar, kritik dan saran yang diberikan oleh ahli materi. Multimedia pembelajaran drill and practice sudah cukup menarik dan layak digunakan pada pembelajaran. Hanya perlu diperbaiki untuk dua soal (Itadakimasu dan Ganbatte). Komentar, kritik, dan saran yang diberikan oleh ahli materi mampu meningkatkan kelayakan multimedia pembelajaran untuk selanjutnya. 
Analisis produk pengembangan adalah simpulan yang diambil berdasarkan analisis data ahli media dan ahli materi tentang produk yang divalidasikan. Berdasarkan angket yang diberikan kepada ahli materi, diperoleh tanggapan bahwa multimedia drill and practice sudah cukup layak. Namun, ahli materi merasa perlu perbaikan pada dua soal yang kurang tepat untuk diberikan kepada siswa. Untuk itu ahli materi menyarankan untuk mengubah soal tersebut agar sesuai dengan materi dan kemampuan siswa.

Berdasarkan angket yang diberikan kepada ahli media, diperoleh tanggapan bahwa multimedia drill and practice secara umum sudah cukup bagus. Namun, ahli media memberikan saran untuk menambahkan audio pada pembuka dan penutup serta penguatan hasil belajar yang ada di akhir. Menambahkan audio pada pembuka dan penutup yang dimaksud adalah saat siswa membuka media tersebut terdapat penguatan berupa suara yang mampu meningkatkan motivasi belajar siswa serta penutup yang memberikan apresiasi kepada siswa yang telah mengerjakan dengan baik. Sedangkan untuk penguatan hasil belajar siswa yang dimaksud adalah memberikan apresiasi di saat hasil belajar siswa muncul agar siswa termotivasi lagi saat belajar. Berdasarkan saran dari ahli media tersebut, maka perbaikan dilakukan terhadap multimedia dengan menambahkan audio pembuka dan penutup disertai dengan penguatan terhadap hasil belajar siswa.

\section{PEMBAHASAN}

Penelitian ini bertujuan untuk mengembangkan multimedia pembelajaran drill and practice dalam bentuk soal Bahasa Jepang Ungkapan Sehari-hari yang valid dan layak digunakan peserta didik. Bahasa Jepang adalah pengetahuan yang harus diterapkan di kehidupan sehari-hari, semakin sering berlatih dan praktik maka peserta didik akan menguasainya dengan cepat, dengan adanya multimedia pembelajaran maka pembelajaran akan lebih efektif.

Sejatinya belajar adalah untuk memperoleh pengalaman yang baru, yang bisa meningkatkan kualitas diri namun, pembelajaran Bahasa Jepang yang dilaksanakan di SMAN 9 Malang adalah pembelajaran klasikal karena pembelajarannya berpusat pada guru sebagai pengelola kelas. Saat ini, pembelajaran seharusnya berpusat pada peserta didik. Setiap peserta didik memiliki latar belakang, kondisi, bakat dan minat yang berbeda-beda. Sehingga kemampuan peserta didik untuk mencerna materi yang disampaikan oleh guru pun berbeda pula. Oleh karena itu, menggunakan multimedia akan membantu pembelajaran siswa lebih dominan dibandingkan guru, tugas gutu hanya membimbing memastikan siswa dapat mengoperasikan multimedia pembelajaran tersebut dengan baik dan benar.

Mediawati (2011:68), penggunaan media pembelajaran dapat meningkatkan motivasi dan minat siswa, menunjang peserta didik dalam mengembangkan kemampuan materi, menyampaikan data yang menarik dan benar serta memudahkan peserta didik saat belajar. Jadi, ketika peserta didik diberikan sesuatu yang baru berupa multimedia pembelajaran drill and practice Bahasa Jepang Ungkapan Sehari-Hari, maka secara psikologis peserta didik akan mempunyai rasa ketertarikan. Rasa ketertarikan itulah yang nantinya membuat siswa termotivasi untuk belajar bahasa asing yang menurut peserta didik sulit dipahami.

Media harus meningkatkan motivasi siswa dalam belajar. Media pembelajaran harus menarik, dengan begitu siswa antusias dalam pembelajaran. Motivasi belajar siswa erat kaitannya dengan prestasi belajar yang diperoleh. Ketika peserta didik termotivasi, maka prestasi belajarnya pun akan meningkat.

Tujuan pengembangan melalui metode drill and practice agar peserta didik mendapatkan umpan balik dari apa yang dikerjakan. Input berasal dari jawaban yang dipilih atau dimasukkan oleh pengguna dan output berupa hasil dari menjawab soal-soal latihan yang berbentuk nilai. Soal 
Bahasa Jepang Ungkapan Sehari-Hari dikembangkan dalam bentuk .exe yang bisa dioperasikan pada laptop/PC.

Soal Bahasa Jepang Ungkapan Sehari-Hari merupakan media pembelajaran menggunakan metode drill and practice. Media pembelajaran dapat digunakan menggunakan komputer karena pertimbangan menggunakan komputer sebagai alat pengoperasian media adalah dapat diprogram untuk menampilkan ulang apa yang telah ditampilkan tanpa batas. Tidak semua peserta didik mampu menyerap informasi sama banyaknya dengan yang lain. Maka dari itu pengulangan merupakan tindakan tepat untuk menyelesaikan ketimpangan tersebut.

Menggunakan komputer untuk pembelajaran bahasa telah terbukti tidak hanya menarik tetapi juga positif dan merangsang bagi banyak guru dan pelajar bahasa (Ghasemi, 2011). Siswa mempunyai keadaan yang berbeda antara satu dengan yang lainnya. Tidak semua siswa yang ada di dalam kelas berada dalam kondisi siap menerima pelajaran. Dengan digunakannya soal Ungkapan Sehari-Hari peserta didik akan menaikkan intensitas minat terhadap pembelajaran Bahasa Jepang. Karena pada dasarnya manusia cenderung penasaran dengan sesuatu yang baru. Pada saat itulah atensi peserta didik akan tertuju. Dengan begitu, kondisi siswa yang semulanya tidak dapat memahami pelajaran menjadi dapat memahami.

Metode drill and practice umumnya digunakan untuk pembelajaran matematika konsep dan bahasa (Heinich, dkk, 2002). Sebagaimana yang kita ketahui, Bahasa Jepang merupakan bahasa asing yang perlu dikuasai selain bahasa ibu yaitu bahasa Indonesia. Maka, soal Ungkapan SehariHari dengan metode drill and practice sangat sesuai apabila diterapkan sebagai media pembelajaran Bahasa Jepang. Bahasa Jepang merupakan ilmu yang berbentuk konsep, sehingga harus dipraktikkan dan dihafalkan agar dapat memahami materi secara utuh.

Soal Bahasa Jepang Ungkapan Sehari-Hari dibuat dengan mempertimbangkan konsep pembelajaran student center. Dengan adanya soal Bahasa Jepang Ungkapan Sehari-Hari, peserta didik dapat me-review ulang materi yang telah disampaikan melalui menjawab soal-soal latihan. Di dalamnya terdapat menu "Lihat Nilai" untuk mengecek jawaban yang telah dikerjakan oleh pengguna. Peserta didik juga dapat mengerjakan ulang soal-soal seperti sebelumnya. Soal-soalnya yang ditampilkan pada tiap kali mencoba lagi.

Jenis soal Bahasa Jepang Ungkapan Sehari-hari yang disajikan sangat beragam. Menyajikan 10 soal yang terdiri dari Ungkapan Sehari-Hari yang sering digunakan oleh masyarakat Jepang. Setiap butir soal pengguna diberikan waktu 15 detik untuk menyelesaikan. Diberi waktu untuk melatih peserta didik berpikir cepat serta melatih daya ingat peserta didik mengenai materi yang telah dipelajari. Macam-macam bentuk soal mulai dari Multiple Choice, True/False, soal audio, soal gambar, dan soal teks.

Materi yang disampaikan berupa bentuk kata yang merupakan teks maupun ucapan. Pendapat ini sesuai dengan yang disampaikan oleh Rusman, "Model drill and practice adalah model dalam pembelajaran dengan melatih siswa terhadap pembelajaran yang sudah diberikan". Drill and practice dimulai dengan informasi yang telah disajikan bagaimana mengoperasikan media tersebut. Setelah paham dengan informasi yang telah dibuat, media menampilkan soal-soal untuk melatih siswa dalam memahami materi.

Pada bagian akhir drill and practice akan ditampilkan nilai yang diperoleh siswa dari soal yang telah dikerjakan apakah siswa sudah menguasai materi atau tidak menguasai materi, jika dirasa kurang menguasai materi maka siswa maka siswa dapat mengulang kembali mengerjakan soal yang tersedia hingga siswa mampu memahami materi tersebut. Dalam mengoperasikan multimedia drill and practice masih diperlukan peran guru untuk memantau siswa, sebenarnya siswa sudah dibantu 
oleh petunjuk dalam program itu sendiri namun, peran guru yang dibutuhkan disini hanya untuk memastikan siswa belajar dengan disiplin hingga menyelesaikan semua tahapan pada multimedia drill and practice. Kritik dan saran dari ahli materi yaitu merevisi beberapa soal yang dibuat. Kritik dan saran dari ahli media untuk memberikan audio pembuka dan penutup serta penguatan untuk hasil belajar siswa.

\section{SIMPULAN}

Berdasarkan uji validasi yang sudah dilaksanakan didapatkan 92\% dari ahli materi dan 93\% dari ahli media. Dengan hasil tersebut soal Bahasa Jepang Ungkapan Sehari-Hari sudah dapat diterapkan dalam pembelajaran. Baik pembelajaran di dalam kelas dan pembelajaran mandiri. Soal Bahasa Jepang Ungkapan Sehari-Hari juga mendapat reaksi yang sangat baik dari ahli materi yang merupakan guru bahasa Jepang. Dari dua uji coba yang dilaksanakan diperoleh hasil persentase yang seluruhnya memenuhi kriteria valid, sehingga dapat disimpulkan bahwa produk multimedia drill and practice ini layak digunakan dalam pembelajaran.

\section{DAFTAR RUJUKAN}

Ana Mualimah, Henry Praherdhiono, Eka Pramono Adi. 2019. Pengembangan Kuis Interaktif Nahwu Sebagai Media Pembelajaran Drill And Practice Pada Pembelajaran Nahwu Di Pondok Pesantren Salafiyah Putri Al-Ishlahiyah Malang. Jurnal Kajian Teknologi Pendidikan, 2(3).

Anderson, J \& Bower, G. 1974. A Propositional Theory of Recognition Memory. Springer Link, 2(3), 406412.

Antika, R.R. 2014. Proses Pembelajaran Berbasis Student Centered Learning (Studi Deskriptif di Sekolah Menengah Pertama Islam Baitul 'Izzah, Nganjuk). Biokultur, 3(1), 251-263.

Candra, B.S \& Sudarso. 2014. Penerapan Model Pembelajaran Drill and Practice terhadap Hasil Belajar Chest Pass pada Permainan Bola Basket (Studi pada Siswa Kelas X SMA Negeri 1 Kota Mojokerto). Jurnal Pendidikan Olahraga dan Kesehatan, 2(1), 141-145.

Daryanto, D. 2013. Media Pembelajaran Perannya Sangat Penting dalam Mencapai Tujuan Pembelajaran. Yogyakarta: Gava Media.

Dyas Nurika P., Punaji S., Arafah Husna. 2020. Pengembangan Multimedia Tutorial sebagai Suplemen pada Mata Pelajaran Kimia Materi Asam dan Basa Kelas XI. Jurnal Inovasi dan Teknologi Pendidikan, 6(2).

Fauzia, N. 2018. The Use of Drill, Vocabulous (Vocabulary Various) and Computer Assisted Language Learning (Call) in Learning Vocabulary. Journal of Learning Teaching Adi Buana, 3(1), 11-27.

Ghasemi, B., Hashemi, M., \& Bardine, S. H. (2011). The Capabilities of Computers for Language Learning. Procedia - Social and Behavioral Sciences, $2858-62$.

Heinich, R., Molenda, M., Russel, J. D., \& Smaldino, S. E. (2002). Instructional Media and Technologies for Learning 7th Edition. New Jersey: Pearson Education.

Julianti, K \& Putrama, I. 2018. Pengaruh Media Augmented Reality Tata Cara Penulisan Huruf Jepang (Hiragana dan Katakana) pada Mata Pelajaran Bahasa Jepang terhadap Hasil Belajar Siswa. E-Jurnal Undiksha, 7(3), 45-49.

Lee, W \& Owens, D. 2004. Multimedia-Based Instructional Design. San Francisco: Pfeiffer.

Lukman Arief N., I Nyoman Sudana D., Agus W. 2018. Pengembangan Multimedia Interaktif Mata Pelajaran IPA Pokok Bahasan Sistem Peredaran Darah Manusia Untuk Kelas VIII SMP Wahid Hasyim Malang. Jurnal Kajian Teknologi Pendidikan, 1(3).

Mayer, R. 2009. Multimedia Learning - Prinsip dan Aplikasi. Yogyakarta: Pustaka Belajar.

Mediawati, E. 2011. Pembelajaran Akutansi Keuangan melalui Media Komik untuk Meningkatkan Prestasi Mahasiswa. Jurnal Penelitian Pendidikan, 12(1), 68-76.

Merra R., Saida U., Agus W. 2018. Pengembangan Multimedia Interaktif Berbasis Mobile Learning Pokok Bahasan Perkembangan Teori Atom Mata Pelajaran Kimia Kelas X Sma Panjura Malang. Jurnal Inovasi dan Teknologi Pembelajaran, 4(2).

Munir. 2015. Multimedia Konsep \& Aplikasi dalam Pendidikan. Bandung: Alfabeta. 
Mochammad Farid Y., Anselmus JE T., Agus W. 2017. Pengembangan Multimedia Pembelajaran Interaktif Ipa Materi Atmosfer Bumi Kelas Viii Smpn 3 Tulungagung. Edcomtech Jurnal Kajian Teknologi Pendidikan, 2(1).

Novita Sholehatul U., Eka Pramono A., Saida U. 2019. Multimedia Tutorial Untuk Menumbuhkan Minat Baca Anak Adhd (Attention Deficit Hyperactivity Disorder). Jurnal Kajian Teknologi Pendidikan, 2(1).

Nur Fauzia (2018). The Use Of Drill, Vocabulous (Vocabulary Various) And Computer Assisted Language Learning (Call) In Learning Vocabulary. 11-27.

Padlurrahman., Hary Murcahyanto (2014). Pengembangan Paket Pembelajaran Bahasa Indonesia Berbasis Drill And Practice Melalui Model Pembelajaran Berbantuan Komputer : Analisis Kebutuhan Di SMA/MA Kabupaten Lombok Timur.

Paivio, A. 2006. Dual Coding Theory and Education. USA: The University of Michigan School of Education. Roestiyah, N.K. 2010. Strategi Belajar Mengajar. Jakarta: Rineka Cipta.

Saraswati, L., Sugihartini, N., \& Prandnyana, I. 2018. Pengaruh Penggunaan Media Pembelajaran E-Learning Quipper School terhadap Hasil Belajar Lintas Minat Biologi pada Siswa Kelas X Bahasa Semester Genap di SMA Negeri 1 Sawan. E-Jurnal Undiksha, 7(3). 68-76.

Seels, B.B \& Richey, R.C. 2012. Instructional Technology: The Definition and Domains of the Field 1994 Edition. Charlotte: Information Age Publishing.

Shalahuddin, M. 1987. Metodologi Pengajaran Agama. Surabaya: Bina Ilmu.

Shinta Kusuma W., Punaji S., Arafah H. 2019. Pengembangan Multimedia Tutorial Mata Pelajaran Ipa Pokok Bahasan Sistem Tata Surya Kelas Vii Mts Raudlatul Ulum Karangploso. Jurnal Kajian Teknologi Pendidikan, 2(1).

Sihkabuden. 2011. Media Pembelajaran. Malang: Departemen Pendidikan Nasional Universitas Negeri Malang Fakultas Ilmu Pendidikan.

Siska Kusumawardani, Zaitun (2018). Drill Strategy In Memorizing Short Surah Of Holy Qur'an Of The $3^{\text {rd }}$ Grades Of SD Labschool FIP UMJ. Drill Strategy, Effectiveness, Short Surah Of Holy Qur'an. 847.

Sugiyono. 2011. Metodologi Penelitian Kuantitatif, Kualitatif, dan R\&D. Bandung: Alfabeta Publishing. 